Revista Eletrônica de Direito Processual - REDP.

Rio de Janeiro. Ano 11. Volume 18. Número 1. Janeiro a Abril de 2017

Periódico Quadrimestral da Pós-Graduação Stricto Sensu em Direito Processual da UERJ

Patrono: José Carlos Barbosa Moreira. ISSN 1982-7636. pp. 346-376

www.redp.uerj.br

\title{
PREMISSAS PARA A MELHOR COMPREENSÃO DA DINAMIZAÇÃO DO ÔNUS DA PROVA NO NOVO CPC ${ }^{1}$
}

\section{DYNAMIC ALLOCATION OF THE BURDEN OF PROOF IN THE NEW \\ PROCEDURAL LAW - PREMISES FOR ITS BETTER UNDERSTANDING}

Sabrina Nasser de Carvalho

Defensora Pública do Estado de São Paulo; Pós-graduada em

Processo Civil pela Pontifícia Universidade Católica de São

Paulo; Mestre em Processo Civil pela Universidade São

Paulo; Doutoranda em Processo Civil pela Universidade São

Paulo; Professora de Direitos Difusos no Curso FMB.

sabrina.nasser@outlook.com

RESUMO: Este artigo pretende discutir a dinamização do ônus da prova, que foi expressamente contemplada no Novo Código de Processo Civil. Para tanto, o texto discorre sobre as premissas históricas e conceituais do ônus da prova, iniciando por uma leitura dos doutrinadores clássicos sobre a matéria. Por fim, para melhor compreender este princípio, que altera o paradigma processual, analisam-se seus fundamentos constitucionais, a compreensão contemporânea dos poderes instrutórios do órgão julgador e os requisitos legais, a fim de delinear as características e requisitos deste novo instituto.

PALAVRAS-CHAVE: ônus probatório - dinamização do ônus da prova - Novo CPC

ABSTRACT: This paper aims at discussing making the burden of proof dynamic, which was explicitly contemplated in the New Code of Civil Procedure. Therefore, the text discusses the historical and conceptual premises of the burden of proof, beginning with a comprehension of the classical masters. Finally, in order to understand better this principle that changes the procedural paradigm, its constitutional foundations, the contemporary

\footnotetext{
${ }^{1}$ Artigo recebido em 15/02/2017 e aprovado em 18/04/2017.
} 
Revista Eletrônica de Direito Processual - REDP.

Rio de Janeiro. Ano 11. Volume 18. Número 1. Janeiro a Abril de 2017

Periódico Quadrimestral da Pós-Graduação Stricto Sensu em Direito Processual da UERJ

Patrono: José Carlos Barbosa Moreira. ISSN 1982-7636. pp. 346-376

www.redp.uerj.br

understanding of the evidentiary powers of the judicial body and its legal requirements are analyzed, so as to outline the features and requirements of this new institute.

KEYWORDS: Burden of Proof - Dynamic allocation of the Burden of Proof- New Procedural Law.

\section{QUESTÕES PRELIMINARES E CONCEITUAIS}

A dinamização do ônus da prova é matéria compreendida dentro de um contexto pós-moderno nas ciências jurídicas, seja no seu aspecto temporal, seja por sua essência e conteúdo $^{2}$, que refletem as premissas do moderno processo civil. A ilustração mais clara do aspecto temporal é o fato de que, no Brasil, a despeito de o movimento doutrinário da defesa da dinamização da regra estática já vir se consolidando ao longo dos anos, a questão apenas ganhou corpo normativo expresso com a Lei 13.105/15, o Novo Código de Processo Civil.

Deste modo, considerando o relativo impacto que o novo princípio irá proporcionar ao sistema jurídico, propõe-se a discussão dos elementos e requisitos que perfazem este novo contexto de distribuição do ônus da prova, o que exige a releitura de institutos processuais elementares e tradicionais, não para negar-lhes a construção histórica de seu conteúdo e significado, mas apenas para inseri-los na dinamização consentânea com o período contemporâneo, a fim de que possam desbordar a rigidez da estabilidade estrita para adequarem-se às particularidades do caso concreto, visando sempre avançar nas linhas evolutivas do Direito Processual Civil para aperfeiçoá-lo como um instrumento de realização da justiça.

\section{1. Ônus Subjetivo e Objetivo da Prova}

Para a incidência da aplicação concreta da lei, não basta o substrato normativo, fazendo-se necessário o desvendamento dos fatos por meio do material probatório carreado aos autos. Portanto, da mesma forma que a interpretação dos princípios e das regras são

\footnotetext{
2 COUTO, Camilo José D’Avila. Dinamização do ônus da Prova: teoria e prática. Tese de Doutorado. Universidade de São Paulo. 2011. p. 96.
} 
Revista Eletrônica de Direito Processual - REDP.

Rio de Janeiro. Ano 11. Volume 18. Número 1. Janeiro a Abril de 2017

Periódico Quadrimestral da Pós-Graduação Stricto Sensu em Direito Processual da UERJ

Patrono: José Carlos Barbosa Moreira. ISSN 1982-7636. pp. 346-376

www.redp.uerj.br

essenciais para o alcance de uma decisão justa, a correta avaliação dos fatos também se mostra necessária para o atingimento de uma escorreita prestação jurisdicional.

Diante de sua importância para um julgamento justo da causa, a prova é erigida ao status de garantia da parte de levar ao juiz elementos destinados ao convencimento judicial sobre a existência ou inexistência dos fatos. Neste sentido, a prova é compreendida dentro do espectro da garantia do contraditório ${ }^{3}$.

A determinação sobre qual sujeito processual deverá se incumbir de provar determinados fatos e as consequiências de eventual omissão são questões regidas pelos efeitos jurídicos afetos ao denominado ônus probatório. Sobre este aspecto, a doutrina divide o ônus probatório em duas perspectivas: uma subjetiva, direcionada às partes, e outra objetiva, que tem como alvo o órgão julgador, e, deste modo, atua como critério de decisão ${ }^{4}$.

O ônus subjetivo da prova, também denominado ônus formal, estabelece a relação entre os fatos a serem provados e os litigantes, para então se concluir quem deve provar determinado fato ou a quem interessa que se produza certa prova, indicando, assim, qual litigante poderá ser afetado em caso de falta da referida prova no processo ${ }^{5}$. Trata-se de regra destinada às partes, de modo a franquear um direcionamento de conduta no decorrer da atividade probatória. Neste sentido, o ônus subjetivo da prova relaciona-se justamente à ideia de risco anteriormente desenvolvida. A ciência prévia acerca de quem incumbe a produção da prova mostra-se como verdadeiro alerta aos litigantes sobre a possibilidade de se arcar com os prejuízos decorrentes de sua não comprovação, ou seja, sobre os riscos de não produzir as provas adequadas e necessárias à demonstração do direito material pretendido 6 .

É certo que, na prática, o que interessa é saber se as provas necessárias à demonstração dos fatos subjacentes à demanda foram carreadas aos autos ou não. Uma vez

\footnotetext{
${ }^{3}$ LOPES, João Batista. Direito à Prova, Discricionariedade e Fundamentação da Sentença. In: DIDIER Jr., Fredie [et. al. ] (coord.). Direito Probatório. Jus PodiVm. 2016. p. 51.

4 "La carga de la prueba realiza dos funciones: la una consistente em dar al juez un critério, a base del cual decidir em todo caso, a fin de evitar un non liquet; la otra que se concreta em el estimulo a la actividad procesal de las partes" (MICHELI, Gian Antonio. La carga de la prueba. Buenos Aires: Ed. Ejea, 1961p. 97).

5 CREMASCO, Suzana Santi. A Distribuição Dinâmica do Ônus da Prova. Rio de Janeiro: GZ Editora, 2009. p. 30.

${ }^{6}$ PIRES, Cristiane Pedroso Pires. Distribuição Dinâmica do ônus da Prova. Mestrado em Direito pela Universidade São Paulo sob orientação do Professor José Carlos Baptista Puoli. São Paulo, 2014. p. 29.
} 
Revista Eletrônica de Direito Processual - REDP.

Rio de Janeiro. Ano 11. Volume 18. Número 1. Janeiro a Abril de 2017

Periódico Quadrimestral da Pós-Graduação Stricto Sensu em Direito Processual da UERJ

Patrono: José Carlos Barbosa Moreira. ISSN 1982-7636. pp. 346-376

www.redp.uerj.br

que as provas estejam nos autos, pouco ou nada interessa saber quem as colacionou, se a parte onerada, a parte contrária ou se tratou de resultado advindo dos poderes instrutórios do órgão julgador? ${ }^{7}$.

Conforme será desenvolvido mais a frente, com o aumento dos poderes do magistrado, que repercutiu com largo impacto em matéria probatória, e com a releitura do Princípio Dispositivo, o aspecto subjetivo do ônus da prova acabou por sofrer uma redução em sua importância ${ }^{8}$, o que não significa que eliminou a pertinência da manutenção de seus efeitos jurídicos. Sobre este aspecto, preconizado sobre a lição de Barbosa Moreira, a força do ângulo psicológico do ônus subjetivo não pode ser menosprezada, pois não é exato concluir que a mera possibilidade de que a prova favorável a uma das partes possa resultar do esforço do juiz ou da colaboração da parte contrária seja suficiente para tranquilizar o litigante a quem incumbe o encargo a ponto de este não engendrar esforços para se desincumbir de seu ônus ${ }^{9}$.

Nesta linha de intelecção, não é correto afirmar que o princípio da aquisição ou comunhão da prova e o aumento dos poderes instrutórios do órgão julgador tenham eliminado ou substituído o ônus imputado às partes sobre a sua atividade probatória. Repisa-se que tais princípios e poderes podem ter atenuado o aspecto subjetivo do ônus da prova, já que resguardam a vinda das provas aos autos por outros meios, mas o encargo probatório das partes, ab initio, se mantém hígido. Como destacado por Suzana Santi Cremasco, cuida-se de elementos complementares que atuam de forma sucessiva: ônus subjetivo, iniciativa probatória do juiz, valoração da prova e ônus objetivo, todos com o

\footnotetext{
7 “Os resultados da atividade instrutória são apreciados pelo órgão judicial sem qualquer valoração, positiva ou negativa, desse comportamento. Se persistiu a obscuridade, em nada aproveita à parte onerada alegar que fez, para dissipá-la, tudo que estava ao seu alcance, e portanto nenhuma culpa se lhe pode imputar. Inversamente, se obscuridade cessou para dar lugar à certeza da ocorrência do fato, em nada prejudica à parte onerada a circunstância de que ela própria não tenha contribuído, sequer com parcela mínima, e ainda que pudesse fazê-lo , para a formação do convencimento judicial, devendo-se o êxito, com exclusividade, a outros fatores". (BARBOSA MOREIRA, José Carlos. Julgamento e Ônus da Prova. In: Temas de Direito Processual: segunda série. Saraiva, São Paulo, 1988. p. 75).

${ }^{8}$ FORNACIARI, Fernando Hellmeister Clito. Ônus da Prova no Processo Civil. Dissertação de Mestrado na Faculdade de Direito da Universidade São Paulo, sob orientação do Professor José Rogério Cruz e Tucci. São Paulo, 2005.

${ }^{9}$ BARBOSA MOREIRA, José Carlos. “A função social do processo civil moderno e o papel do juiz e das partes na direção e na instrução do processo”. In: Revista de Processo. São Paulo, n. 37, jan/mar. 1985. p.78.
} 
Revista Eletrônica de Direito Processual - REDP.

Rio de Janeiro. Ano 11. Volume 18. Número 1. Janeiro a Abril de 2017

Periódico Quadrimestral da Pós-Graduação Stricto Sensu em Direito Processual da UERJ

Patrono: José Carlos Barbosa Moreira. ISSN 1982-7636. pp. 346-376

www.redp.uerj.br

mesmo fim, qual seja, o de proporcionar um pronunciamento judicial mais adequado possível ${ }^{10}$.

Portanto, o aspecto subjetivo do ônus da prova mantém a sua relevância e importância para o sistema processual atual, ao menos como critério orientador da conduta da atividade das partes, a fim de que tenham conhecimento prévio sobre a quem incumbe a demonstração de determinado fato. Esta conclusão será de razoável pertinência quando a discussão versar sobre o momento processual adequado da distribuição dinâmica do ônus da prova.

De outro lado, o ônus objetivo da prova tem o seu valor quando as provas dos fatos relevantes ao julgamento não forem carreadas aos autos ou, ainda que as tenham sido, que a situação fática ainda se mantenha obscura. Este é o único aspecto que tem relevância para o órgão julgador, pois é com arrimo nesta perspectiva que se projetará a regra para pautar o julgamento em caso de dúvida e da impossibilidade de esclarecimento dos fatos. Fincado na premissa de que o juiz deve julgar em qualquer hipótese, ainda que diante da insuficiência das provas e mesmo diante da ausência de condições de seu convencimento sobre os fatos, o ônus objetivo da prova franqueia embasamento para o proferimento de uma decisão, atingindo assim o escopo social de pacificação de interesses a que visa o processo. Em conclusão: o ônus objetivo da prova trata-se de regra de julgamento que, diante da impossibilidade do non liquet, busca assegurar a prestação jurisdicional.

No que pertine à estruturação do ônus da prova, Eduardo Cambi alerta para a estreita imbricação entre o aspecto subjetivo e objetivo do ônus da prova. Afirma Cambi que a falta de clareza que força o juiz aplicar o ônus da prova em sentido objetivo é inseparável do risco que pesa sobre a parte que não produz os fatos necessários para a aplicação da norma jurídica invocada ${ }^{11}$. Portanto, pode-se afirmar que o aspecto subjetivo e objetivo do ônus da prova são complementares e não excludentes. Assim, a melhor forma de compreender a regra legal sobre a distribuição do ônus da prova é fazer com que ela atenda às duas funções.

\footnotetext{
${ }^{10}$ Op. cit., p. 36.

11 "Com efeito, o juiz, na impossibilidade de resolver essa dúvida e ter elementos suficientes para formar a sua convicção, não tem outra saída senão contrariar os interesses da parte que, desde o início do processo, era responsável pela demonstração desse suporte fático. Portanto, o aspecto objetivo do ônus da prova está ligado, intrinsecamente, ao subjetivo, não podendo ser desprezado". (CAMBI, Eduardo. A Prova Civil: admissibilidade e relevância. São Paulo: Revista dos Tribunais. p. 2006. p. 318)
} 
Revista Eletrônica de Direito Processual - REDP.

Rio de Janeiro. Ano 11. Volume 18. Número 1. Janeiro a Abril de 2017

Periódico Quadrimestral da Pós-Graduação Stricto Sensu em Direito Processual da UERJ

Patrono: José Carlos Barbosa Moreira. ISSN 1982-7636. pp. 346-376

www.redp.uerj.br

Estas premissas serão importantes para embasar uma discussão que será feita mais a frente sobre o momento adequado de distribuição do ônus da prova pelo órgão julgador, quando então o enfoque quanto à atividade das partes se mostrará bastante relevante.

\section{TEORIA ESTÁTICA DO ÔNUS DA PROVA}

\subsection{Base Histórica e Conceitual}

A gênese das regras atinentes à distribuição das cargas probatórias remonta ao Direito Romano, que acabou por exercer larga influência nas teorias clássicas sobre o assunto. À época, já vigia a regra do iura novit curia, dispensando as partes do ônus de provar determinada norma jurídica. No entanto, cabia às partes comprovar as quaestiones facti, com a seguinte regra de distribuição deste ônus: incumbe ao autor deduzir os fatos declinados na intentio e, ao réu, aqueles aportados na exceptio ${ }^{12}$. Em outras palavras, cabia ao autor demonstrar os fatos constitutivos de sua pretensão e ao réu apenas os novos fatos apresentados em exceção. Neste sentido, vigia a máxima "ei incumbit probatio qui dicit, non qui negat", ou seja, o "ônus da prova incumbe a quem afirma e não a quem nega". O critério para a distribuição deste ônus encontrava-se na identificação daquele responsável por trazer a afirmação ao processo, não havendo qualquer responsabilidade da parte que se limitasse a apenas negar as afirmações exaradas pelo litigante contrário.

Com o avanço da ciência processual, a matéria foi evoluindo, despertando a atenção de grandes processualistas, os quais fraquearam importantes contribuições para a construção de teorias acerca do ônus da prova ${ }^{13}$.

Giuseppe Chiovenda foi o responsável pela construção da teoria da distribuição do ônus da prova preconizada sobre a natureza dos fatos a serem provados. Nos termos da doutrina de Chiovenda, as regras de distribuição do ônus da prova decorrem da oportunidade e do interesse que as partes terão de provar os fatos considerados como verdadeiros para o juiz.

Baseia-se o autor para a fundamentação de sua teoria no princípio da normalidade ou da anormalidade dos fatos aportados pelas partes. Defende Chiovenda que as condições gerais de validade de todos os negócios, em razão de sua normalidade, são de

12 AZEVEDO, Luiz Carlos de. CRUZ E TUCCI, José Rogério. Lições de História do Processo Civil Romano. São Paulo: Revista dos Tribunais, 2001. p. 124.

${ }^{13}$ Nomes como Bentham, Webber, Benthmann-Holweg, Fitting, Gianturco, Demogue, Betti, Chiovenda e Carnelutti dedicaram-se à discussão e a consequente evolução da teoria. 
Revista Eletrônica de Direito Processual - REDP.

Rio de Janeiro. Ano 11. Volume 18. Número 1. Janeiro a Abril de 2017

Periódico Quadrimestral da Pós-Graduação Stricto Sensu em Direito Processual da UERJ

Patrono: José Carlos Barbosa Moreira. ISSN 1982-7636. pp. 346-376

www.redp.uerj.br

responsabilidade do autor. Por outro, a falta destas condições, por se tratar de questão excepcional, deve ser imputada ao réu ${ }^{14}$.

Pelo que se pode depreender, para Chiovenda, incumbe ao autor provar os fatos constitutivos de seu direito, ou seja, os fatos que normalmente produzem determinados efeitos jurídicos, cabendo ao réu a demonstração dos fatos impeditivos, ou seja, a falta daqueles fatos que normalmente concorrem com os fatos constitutivos e que os impedem de produzir os regulares efeitos jurídicos ${ }^{15}$. De todo modo, a mera negação dos fatos afirmados pela outra parte não atrai ao réu qualquer ônus probatório ${ }^{16}$.

Enquanto Chiovenda preconiza sua teoria na defesa de que o interesse probatório das partes subjaz no interesse da comprovação dos fatos, Carnelutti pauta a sua teoria sobre o interesse na afirmação dos fatos. Ou seja, para ele, o ônus recai sobre o autor quando este tem interesse na afirmação de fatos que constituem a sua pretensão e, incumbe ao réu, quando os fatos consubstanciam a exceção por ele manejada, em que são veiculadas as condições impeditivas, modificativas ou extintivas do direito do autor ${ }^{17}$.

Deste modo, a despeito de algumas diferenças que possam haver entre estes clássicos doutrinadores, pode-se afirmar que ambos defendem que a distribuição do ônus da prova se paute na classificação dos fatos como constitutivos, impeditivos, extintivos e modificativos do direito.

Como verá demonstrado, a teoria clássica italiana, assim como ocorreu em outros institutos processuais, influenciou o nosso ordenamento jurídico, inclusive quanto às regras probatórias, conforme será analisado a seguir.

\subsection{Teoria Estática e sua Insuficiência Normativa}

\footnotetext{
${ }^{14}$ CHIOVEndA, Giuseppe. Instituições do Direito Processual Civil. v. 2., Trad. Paolo Capitanio. $2^{\mathrm{a}}$ Ed. São Paulo: Bookseller, 2000. p. 382.

${ }^{15}$ Idem, ibidem p. 451-452. .

16 "Somente quando o autor trouxer provas idôneas para demonstrar a existência do fato constitutivo de seu direito tem o réu de diligenciar, de seu lado, a sua prova. Mas isto, a seu turno, pode ocorrer com dois propósitos: a) Ou o réu tende, somente, como já dissemos, a provar fatos que provam a inexistência do fato provado pelo autor, de modo direto ou indireto (e dizem-se motivos), e temos aí a simples prova contrária ou contraprova; Ou o réu, sem excluir o fato provado pelo autor, afirma e prova um outro que lhe ilide os efeitos jurídicos, e aí temos a verdadeira prova do réu, a prova de exceção dizem-se motivos), e temos aí a simples prova contrária ou contraprova; b) Ou o réu, sem excluir o fato provado pelo autor, afirma e prova um outro que lhe ilide os efeitos jurídicos, e aí temos a verdadeira prova do réu, a prova de exceção”. (Idem, ibidem p. 449).

${ }^{17}$ CARNELUTTI, Francesco. Sistema de Derecho Procesal Civil. Tradução Niceto Alcalá-Zamora y Cartillo y Santiago Sentís Melendo. Buenos Aires: UTHEA. 1944. p. 424.
} 
Revista Eletrônica de Direito Processual - REDP.

Rio de Janeiro. Ano 11. Volume 18. Número 1. Janeiro a Abril de 2017

Periódico Quadrimestral da Pós-Graduação Stricto Sensu em Direito Processual da UERJ

Patrono: José Carlos Barbosa Moreira. ISSN 1982-7636. pp. 346-376

www.redp.uerj.br

"Ao autor, quanto ao fato constitutivo de seu direito", e "ao réu, quanto à existência de fato impeditivo, modificativo ou extintivo do direito do autor". Esta regra, contida no artigo 333 do Código de Processo Civil de 1973, abrangia a forma de distribuição do ônus da prova entre as partes. Havia apenas uma flexibilidade desta regra geral: a possibilidade de convenção entre as partes para disporem em sentido contrário, salvo determinadas exceções expressamente previstas, nos termos do parágrafo único do mencionado $\operatorname{artigo}^{18}$.

Este dispositivo, ainda que com algumas alterações lingüísticas, reproduzia o regramento inserto no artigo 209 do Código de Processo Civil de $1939^{19}$. E, assim, os Códigos processuais anteriores espelhavam a teoria criada por Chiovenda da distribuição do ônus probatório, que, como outrora se demonstrou, baseava-se na natureza dos fatos que devem ser objeto de comprovação e na posição ocupada por cada parte no processo ${ }^{20}$.

Estes diplomas processuais consagraram a denominada regra estática do ônus da prova. Estática porque a regra se impõe de forma abstrata e previamente ao conflito de interesses, pautando-se exclusivamente na posição que cada parte ocupa em juízo e na natureza do fato a ser provado.

A rigidez da regra estabelecida no artigo 333 do Código de Processo Civil não permitia que o órgão julgador moldasse a técnica processual à luz das peculiaridades do caso concreto, levando-se em conta a natureza do direito material em questão ou as condições econômicas e técnicas das partes. Ao contrário, estabelecia um critério legal e único de julgamento, que deveria ser aplicado caso o encargo não fosse cumprido pela parte a quem a lei incumbia.

Esta rigidez e inflexibilidade procedimental foi objeto de críticas pela doutrina por não se revelar justa e adequada em determinadas situações. Como se trata de critério de julgamento, a rigidez da regra processual podia levar a um injusto provimento

\footnotetext{
${ }^{18} \mathrm{O}$ parágrafo único do artigo 333 dispunha que era nula a convenção entre as partes sobre o ônus da prova que versasse sobre direitos indisponíveis ou que torne excessivamente difícil a uma parte o exercício do direito.

${ }^{19}$ Art. 209, CPC/39: “O fato alegado por uma das partes, quando a outra o não contestar, será admitido como verídico, se o contrário não resultar do conjunto das provas. $\S 1^{\circ}$ : Se o réu, na contestação, negar o fato alegado pelo autor, a este incumbirá o ônus da prova. $\S 2^{\circ}$ : Se o réu, reconhecendo o fato constitutivo, alegar a sua extinção, ou a ocorrência de outro que lhe obste aos efeitos, a ele cumprirá provar a alegação".

${ }^{20}$ HIGINO NETO, Vicente. Ônus da Prova: teorias da redução do módulo da prova e das provas dinâmicas e compartilhadas. Curitiba: Juruá. 2010. p. 78.
} 
Revista Eletrônica de Direito Processual - REDP.

Rio de Janeiro. Ano 11. Volume 18. Número 1. Janeiro a Abril de 2017

Periódico Quadrimestral da Pós-Graduação Stricto Sensu em Direito Processual da UERJ

Patrono: José Carlos Barbosa Moreira. ISSN 1982-7636. pp. 346-376

www.redp.uerj.br

jurisdicional, afastando, em consequência, a norma processual de sua função constitucional, que é garantir a plena efetividade aos desígnios do direito material e jamais se revelar um óbice à materialização dos valores perfilhados pelo direito substancial.

Importante esclarecer que a crítica da doutrina sempre passou ao largo da defesa pela imprestabilidade da regra em si. Ao contrário, mesmo os doutrinadores que sempre defenderam novas formas de distribuição dos ônus probatórios, reconhecem que, em grande parte dos casos, o critério estático do ônus da prova utilizado pelas nossas leis processuais mostra-se justo e adequado. A ponderação está na insuficiência da adoção rígida e inflexível da visão estática que, em determinados casos, compreendidos inclusive como hipóteses excepcionais, não reflete a igualdade substancial entre as partes, seja em razão da natureza do direito material em pauta, seja em razão da flagrante desigualdade técnica que possa haver entre os litigantes.

Há situações em que o reconhecimento do direito pleiteado por uma das partes é de difícil, quiçá, impossível, demonstração probatória. Por outro lado, pode ocorrer que este empecilho deflagrado na dificuldade ou na impossibilidade de demonstração dos fatos não se revele para a outra parte.

Neste sentido, denota-se a insuficiência da regra estática, que foi consubstanciada pela ideologia reinante no Estado Liberal, marcado pela flagrante desigualdade das posições dos litigantes, sempre escudada pelo mito da igualdade formal ${ }^{21}$.

No contexto atual, permeado pelos valores do Estado Social e Constitucional, e, considerando os novos anseios sociais, faz-se necessário que o processo seja permeado pelos influxos das concepções filosóficas, políticas e culturais que estão plasmadas no direito material, pois refletem as posições ideológicas da sociedade atual. ${ }^{22}$ Não se pode desconsiderar também que a sociedade em que vivemos é plural, com grupos e classes sociais distintos, que culminam também em conflitos dos mais diversos e complexos. Não há razão, portanto, para se padronizar de forma rígida e absoluta o ônus probatório, que,

\footnotetext{
21 "A generalidade e abstracionismo característicos da lei reduziram a distribuição dos ônus probatórios a um dos símbolos da igualdade formal, ao qual não importava a vida real das pessoas e eventuais distinções concretas existentes entre elas. Pretendeu garantir-se, dessa forma, a imparcialidade no tratamento das partes - que por serem "iguais" deveriam ser tratadas sem discriminação - e a segurança jurídica, outorgando às partes a tão prestigiada previsibilidade do procedimento". (CARPES, Artur. Ônus Dinâmico da Prova. Livraria do Advogado: Porto Alegre, 2010. p. 69-70).

${ }^{22}$ BEDAQUE, José Roberto dos Santos. Direito e Processo: influência do direito material sobre o processo. São Paulo: Malheiros, 2009. p. 24.
} 
Revista Eletrônica de Direito Processual - REDP.

Rio de Janeiro. Ano 11. Volume 18. Número 1. Janeiro a Abril de 2017

Periódico Quadrimestral da Pós-Graduação Stricto Sensu em Direito Processual da UERJ

Patrono: José Carlos Barbosa Moreira. ISSN 1982-7636. pp. 346-376

www.redp.uerj.br

aliás, cuida-se de um dos mais importantes fatores aptos a influenciarem a formação da cognição processual.

Como visto, a prova e os efeitos jurídicos que dela emergem constituem institutos basilares e de extrema importância na dinâmica processual. A doutrina erige a disciplina do onus probandi à coluna vertebral do processo civil, demonstrando quão destacado é o seu impacto para a busca da justiça constitucionalmente desejável ${ }^{23}$. E outra conclusão não se poderia colimar: cumprir o escopo jurídico do processo, ou seja, atingir os desígnios concretos do direito material passa pelo correto dimensionamento dos fatos relevantes ao julgamento, que também é função da disciplina probatória. Este correto dimensionamento não se trata de reproduzir os fatos ocorridos ou seguir em busca de uma verdade fática real. Compartilhando com as ponderações de Marinoni, a matéria processual probatória tem por finalidade um papel argumentativo ou, melhor dizendo, a construção retórica dos fatos, com vistas ao convencimento do órgão julgador das assertivas lançadas pelas partes ${ }^{24}$.

Reconhecer estas limitações das técnicas processuais é imprescindível para melhor compreender e interpretar os institutos, mas isso não representa a comodidade de não se perseguir técnicas e valores consentâneos com o alcance de uma elevada probabilidade da ocorrência de determinado fato ou de proporcionar ao juiz condições possíveis e razoáveis para um julgamento procedimentalmente justo. Esta função é imputada ao processo civil e, na perspectiva deste estudo, à matéria do ônus probatório.

\section{PODERES INSTRUTÓRIOS DO JUIZ E SEU IMPACTO NO ÔNUS PROBATÓRIO DAS PARTES}

Como forma de exercício do poder, diante da capacidade de decidir imperativamente, o processo tem, indiscutivelmente, natureza pública. Portanto, o objeto do processo, o direito material, pode até mesmo ser disponível às partes, estar no âmbito de

\footnotetext{
${ }^{23}$ ROSENBERG, Leo. Tratado de derecho procesal civil. 1. ed., v. 2. Buenos Aires: EJEA, 1955, p. 228.

${ }^{24}$ Segundo o autor, a finalidade da prova não tem por objeto a reconstrução dos fatos que servirão de supedâneo para a incidência da regra jurídica abstrata, mas sim de servir como peça de argumentação no diálogo judicial para o convencimento do Estado-jurisdição sobre qual das partes deve ser beneficiada com a proteção judicial. (MARINONI, Luiz Guilherme. ARENHART, Sérgio Cruz. Prova. São Paulo: Revista dos Tribunais. p. 51).
} 
Revista Eletrônica de Direito Processual - REDP.

Rio de Janeiro. Ano 11. Volume 18. Número 1. Janeiro a Abril de 2017

Periódico Quadrimestral da Pós-Graduação Stricto Sensu em Direito Processual da UERJ

Patrono: José Carlos Barbosa Moreira. ISSN 1982-7636. pp. 346-376

www.redp.uerj.br

sua liberdade privada, mas o instrumento que o veicula é dotado de um inegável componente publicista, já que os escopos do processo visam aos fins públicos ${ }^{25}$.

Não se está a desconsiderar os componentes privatistas do processo. A liberdade de demandar é exclusiva da parte, que também tem o ônus de apresentar em juízo os fatos pertinentes à defesa de seu direito. Da mesma forma, não se pode eximir o autor do dever de impulsionar o processo, ainda que em concorrência com o órgão julgador. Mantêm-se, assim, incólume os deveres, ônus e as faculdades das partes.

Modernamente, no entanto, tem-se destacado que o processo civil deve perseguir cada vez mais ao interesse público e à função social, o que acaba por conferir cores mais acentuadas ao conteúdo publicista ${ }^{26}$.

Nesta perspectiva, defende-se que juiz possa intervir de uma forma mais efetiva na condução processual, intervindo, inclusive, para amenizar as eventuais desigualdades identificadas no curso do processo, com o objetivo de possibilitar o maior equilibro entre as partes por meio do instrumento. A proposta é o abandono de uma posição inerte, passiva do órgão julgador, de modo a franquear-lhe poderes para intervir diretamente no iter processual, a fim de que seja outorgada ampla efetividade ao instrumento para fazer valer o direito material.

A discussão não está restrita aos lindes doutrinários. José Carlos Baptista Puoli discorre sobre como as reformas processuais no Brasil refletiram no aumento do poder do órgão julgador nos últimos anos, com vistas a fazer com que o processo cumpra os efeitos desejados pelos consumidores da Justiça ${ }^{27}$.

\footnotetext{
${ }^{25}$ Cândido Dinamarco vislumbra vários escopos do processo que se relacionam aos fins públicos. O escopo jurídico visa à concretização do direito objetivo. A eliminação das insatisfações revela o escopo social do processo, pacificando os conflitos de interesses. O escopo político do processo passa pela visão do processo enquanto instrumento para o exercício do poder, restringindo-o e limitando-o. (DINAMARCO, Cândido Rangel. A Instrumentalidade do Processo. São Paulo: Malheiros, 2009).

26 "Há trinta anos reflete-se, quase por toda a parte, cada vez de forma mais intensa, sobre a atividade do juiz. É verdade que gerações passadas chegaram a discutir sobre os direitos das partes e do juiz, mas, àquela época, linhas marcadamente dogmáticas dominavam o problema. A questão era saber se o princípio da livre disposição das partes em relação ao objeto do processo deveria orientar sua evolução ou se, ao invés disso, orientar o processo deveria ser o papel do princípio inquistório que corresponderia à sua verdadeira "natureza". Nos dias de hoje, entretanto, as reflexões e os postulados de ordem política parecem prevalecer: o papel ativo do juiz é visto em estrita relação com a reivindicação de uma razoável aceleração do processo e com função social deste”. (BAUR, Fritz. “O Papel Ativo do Juiz”. In: Revista de Processo. São Paulo: Revista dos Tribunais, n. 27, jul./set., 1982. p. 187).

27 Como exemplo, menciona Puoli sobre o aumento do poder dos juízes na antecipação de tutela, na concessão do efeito suspensivo e da tutela antecipada recursal, o maior poder do relator nos recursos, os poderes do juiz na tutela específica das obrigações de fazer e não fazer, e, por fim, os poderes do juiz na
} 
Revista Eletrônica de Direito Processual - REDP.

Rio de Janeiro. Ano 11. Volume 18. Número 1. Janeiro a Abril de 2017

Periódico Quadrimestral da Pós-Graduação Stricto Sensu em Direito Processual da UERJ

Patrono: José Carlos Barbosa Moreira. ISSN 1982-7636. pp. 346-376

www.redp.uerj.br

Esta tendência do moderno processo civil ganha ênfase quando o assunto versa

sobre a ampliação dos poderes instrutórios do órgão julgador. O Código Processual de 1973 já elencava amplas possibilidades probatórias ao juiz, resultados claros de luzes publicistas que se irradiam à atividade instrutória ${ }^{28}$.

Nesta mesma linha, o NCPC manteve esta diretiva de alargar os poderes ao magistrado, tornando-o, nos dizeres do artigo 139, o verdadeiro diretor do processo. E o rol de poderes-deveres, descritos neste mesmo dispositivo, é extenso e de largo impacto, incluindo novidades como o poder de polícia (art. 139, inciso VII) e a possibilidade de o juiz flexibilizar o procedimento, com a alteração de prazos processuais e da ordem de produção de provas (art. 139, inciso VI).

Quanto aos poderes instrutórios, o artigo 370 do NCPC manteve a possibilidade de o órgão julgador determinar ex officio a realização de prova imprescindível para o julgamento, alinhando-se, assim, à visão publicista do processo de que os poderes instrutórios do órgão julgador são necessários para uma decisão mais adequada e justa.

A ampliação dos poderes instrutórios do magistrado mostra-se o mais valioso instrumento "corretivo", pois permite "iluminar aspectos da situação fática, até então deixados na sombra por deficiência da atuação deste ou daquele litigante" e "contribui, do ponto de vista prático, para suprir inferioridades ligadas à carência de recursos e de informações, ou à dificuldade de obter o patrocínio de advogados mais capazes e experientes" 29 . Portanto, há quem visualize neste poder-dever uma forma de ressaltar a importância social do processo ${ }^{30}$.

O embasamento que impulsiona o fortalecimento dos poderes instrutórios do órgão julgador consubstanciam, segundo a doutrina, na igualdade material entre as partes e na

tentativa de conciliação. (PUOLI, José Carlos Baptista. Os Poderes do Juiz e as Reformas do Processo Civil. São Paulo: Editora Juarez, 2002. p. 149-211).

${ }^{28} \mathrm{O}$ artigo 130 dispõe expressamente que cabe ao juiz, de ofício, determinar as provas necessárias à instrução do feito; consta como poder-dever do órgão julgador a possibilidade de ordenar o comparecimento pessoal das partes, a fim de interrogá-las (art. 342); inclui como atividade oficiosa do juiz ordenar a exibição de documentos ou coisa em poder de um dos litigantes ou de terceiros (art. 355); requisitar repartições públicas certidões e procedimentos necessários à demonstração da prova das alegações das partes (art. 399); proceder à inspeção de coisas ou pessoas (art. 440); ordenar de ofício a inquirição de testemunhas referidas nas declarações das partes ou das testemunhas ou determinar a acareação de duas ou mais testemunhas (art. 418).

${ }^{29}$ BARBOSA MOREIRA, Barbosa. "A Função Social do Processo Civil Moderno e o Papel do Juiz e das Partes na Direção e na Instrução do processo”. In: Revista de Processo. São Paulo, n. 37, jan/mar. 1985.p. 146.

${ }^{30}$ Idem, ibidem p. 147. 
Revista Eletrônica de Direito Processual - REDP.

Rio de Janeiro. Ano 11. Volume 18. Número 1. Janeiro a Abril de 2017

Periódico Quadrimestral da Pós-Graduação Stricto Sensu em Direito Processual da UERJ

Patrono: José Carlos Barbosa Moreira. ISSN 1982-7636. pp. 346-376

www.redp.uerj.br

busca por um provimento judicial mais justo e consentâneo com a verdade possível e razoável:

“A primeira função do poder oficial em determinar a realização de provas é servir como instrumento de efetivação do princípio isonômico, quando houver desigualdades entre os litigantes que possam ensejar a prolação de decisão manifestamente distorcida, baseada em fatos mal ou não provados.

A segunda função é buscar a verdade dos fatos, possibilitando a formação segura de convicção judicial para o julgamento da lide, nem sempre decorrente única e exclusivamente da atividade probatória das partes, fazendo-se necessária a investigação pelo próprio órgão julgador" ${ }^{\prime 31}$.

Com a ampliação do espectro dos poderes instrutórios do órgão julgador, questionase qual seria o seu impacto em relação aos ônus probatórios destinados às partes.

A leitura mais adequada deste fenômeno é compreender tais poderes como complementares ou integrativos e não substitutivos do ônus subjetivo da prova. E, portanto, compreendê-los como complementares não significa prestigiar a inércia ou a desídia da parte que deveria cumprir o encargo que lhe foi atribuído, deslocando tais atribuições para a responsabilidade do órgão julgador. O escopo é utilizá-lo para afastar as insuficiências não culpáveis e as dificuldades objetivas da atividade probatória em favor da melhor reconstrução (retórica) dos fatos, almejando a justiça da decisão e, em última análise, a sua legitimação social ${ }^{32}$.

José Roberto dos Santos Bedaque esclarece que os poderes instrutórios do juiz não se subordinam às regras sobre o ônus da prova, por se tratarem de institutos diversos e que exercem seus efeitos em momentos também diversos. De acordo com Bedaque, as normas de distribuição do ônus da prova sequer pertencem ao instituto da prova, pois a sua incidência ocorre justamente nas situações de insuficiência desta. Assim, concluiu o autor

${ }^{31}$ CAMPANELli, Luciana Amicucci. Poderes Instrutórios do Juiz e a Isonomia Processual. São Paulo: Juarez de Oliveira. 2006. p. 54)

32 CAMBI, Eduardo. A Prova Civil: admissibilidade e relevância. São Paulo: Revista dos Tribunais. 2006. p. 326-327. 
Revista Eletrônica de Direito Processual - REDP.

Rio de Janeiro. Ano 11. Volume 18. Número 1. Janeiro a Abril de 2017

Periódico Quadrimestral da Pós-Graduação Stricto Sensu em Direito Processual da UERJ

Patrono: José Carlos Barbosa Moreira. ISSN 1982-7636. pp. 346-376

www.redp.uerj.br

que os poderes instrutórios do órgão julgador não eliminam as regras sobre o ônus da prova, até porque a regra poderá incidir, inclusive, quando, ao final, as partes e o juiz dispensaram todos os esforços para a demonstração dos fatos afirmados apresentados em juízo, mas ainda assim estes se encontram imbuídos de dúvidas ${ }^{33}$. Na mesma linha do raciocínio anterior, visualiza nos poderes instrutórios do juiz uma forma eficaz de reduzir, quando possível, a utilização da regra objetiva do ônus da prova, vez que a sua aplicação se trata de um provimento jurisdicional legítimo, mas não necessariamente justo, do ponto de vista substancial ${ }^{34}$.

Em conclusão, faz-se imprescindível aferir a funcionalidade da outorga de se franquear maiores poderes de direcionamento do órgão julgador no processo, para se concluir se os objetivos estão sendo atingidos, sem esbarrar em qualquer garantia dos jurisdicionados, mas, ao contrário, preservando-as. Repisa-se que não se olvida que o processo também é feito do componente privatístico, sendo imprescindível que a questão se paute sobre o equilíbrio entre o público e o privado $^{35}$. Por esta razão, defende-se que o ônus subjetivo da prova mantenha-se sólido, ainda que se reconheça a redução de seu espectro.

Nesta perspectiva de ônus subjetivo da prova e poderes instrutórios do juiz, deve-se buscar a ponderação e o equilíbrio. No contexto, equilíbrio deve ser compreendido como eliminação de excessos de ambos os lados. E, excessos são identificados quando os princípios e regras estiverem desconectados dos reais escopos do processo. Enquanto estes princípios e regras estiverem servindo aos propósitos e expectativas que a sociedade espera do instrumento processual, não há excessos e as reformas neste sentido são bem vindas.

E nem poderia ser diferente em nosso país, marcado pelas graves contradições sociais, econômicas e culturais, que, como já frisado, reproduzem-se nas relações processuais e, em última análise, resvalam-se no direito material. Por esta razão, não se

\footnotetext{
${ }^{33}$ BEDAQUE, José Roberto dos Santos. Poderes Instrutórios do Juiz. São Paulo: Revista dos Tribunais. p. 118-122.

${ }^{34}$ BEDAQUE, José Roberto dos Santos. Op.cit. p. 124.

${ }^{35}$ No artigo "Público e Privado no Processo Civil na Itália", Andrea Proto Pisani assim concluiu: "Gostaria de concluir com uma observação final. Público e privado constituem os componentes intrínsecos de todo o processo civil: é portanto inevitável que qualquer proposta de reforma parta do diverso ponto de equilíbrio que, em relação aos inúmeros nós do processo, se pretende alcançar para a composição deste eterno contraste". (PISANI, Andrea Proto. "Público e Privado no Processo Civil”. Revista da Emerj, v. 4, n. 16, 2001).
} 
Revista Eletrônica de Direito Processual - REDP.

Rio de Janeiro. Ano 11. Volume 18. Número 1. Janeiro a Abril de 2017

Periódico Quadrimestral da Pós-Graduação Stricto Sensu em Direito Processual da UERJ

Patrono: José Carlos Barbosa Moreira. ISSN 1982-7636. pp. 346-376

www.redp.uerj.br

pode negar a socialidade do direito e a politicidade de seu uso, afastando a necessidade de uma nova formação do juiz, tornando-o mais consciente da necessidade de conhecer e interpretar o direito à luz do contexto social, como defende Dalmo Dallari ${ }^{36}$.

\section{TEORIA DA DISTRIBUIÇÃO DINÂMICA DO ÔNUS PROBATÓRIO NO CPC/15}

\subsection{Fundamentos da Teoria Dinâmica do ônus da Prova na Constituição Federal Brasileira}

O direito processual, por regulamentar o poder estatal para a atuação do direito objetivo, tem seus pressupostos e suas linhas fundamentais traçadas pelo direito constitucional e, portanto, é fundamentalmente determinado pelos preceitos insertos na Constituição ${ }^{37}$. Sendo assim, o repositório normativo de base infraconstitucional deve se amoldar aos influxos axiológicos da normativa constitucional.

Tal perspectiva foi reafirmada no artigo $1^{\circ}$ do $\mathrm{CPC} / 15$, a fim de ilidir quaisquer dúvidas de que são os valores constitucionais os vetores de interpretação das normas insertas no recente diploma processual ${ }^{38}$. Pode parecer ocioso insistir na imprescindibilidade da interpretação das normas processuais pelo viés constitucional, diante da claridade que a questão já era posta pela doutrina moderna, mesmo antes da vigência do Novo CPC. De todo modo, a insistência é válida e merece ser reverberada, com vistas a demonstrar o lastro normativo que outorga legitimidade para a revisitação de institutos clássicos, de modo que se busque cada vez mais o aprimoramento contínuo do processo como instrumento pleno de acesso e efetivação da justiça, assim como deseja a nossa Constituição.

Nesta linha de raciocínio, pretende-se demonstrar que a distribuição dinâmica do ônus da prova encontra amplo respaldo nos princípios constitucionais. O princípio da igualdade, disposto no artigo $5^{\circ}$, caput da Constituição Federal, é um deles. Com fulcro na

\footnotetext{
${ }^{36}$ DALLARI, Dalmo de Abreu. O Poder dos Juízes. São Paulo: Saraiva. 1966. p. 94.

37 GRINOVER, Ada Pellegrini. As Garantias Constitucionais do Direito de Ação. São Paulo: Revista dos Tribunais, 1973. p. 12.

38 Art. 1o O processo civil será ordenado, disciplinado e interpretado conforme os valores e as normas fundamentais estabelecidos na Constituição da República Federativa do Brasil, observando-se as disposições deste Código.
} 
Revista Eletrônica de Direito Processual - REDP.

Rio de Janeiro. Ano 11. Volume 18. Número 1. Janeiro a Abril de 2017

Periódico Quadrimestral da Pós-Graduação Stricto Sensu em Direito Processual da UERJ

Patrono: José Carlos Barbosa Moreira. ISSN 1982-7636. pp. 346-376

www.redp.uerj.br

ideologia da solidariedade que se extrai dos objetivos traçados às funções institucionais (art. $3^{\circ}, \mathrm{CF} / 88$ ), compreende-se a referida garantia por seu aspecto substancial e não meramente formal ${ }^{39}$. O princípio da igualdade material, da mesma forma que se torna a força motriz para a exigência de políticas sociais e redistributivas por parte do Estado Social, com vistas à inclusão social, também deve ser transposta ao processo, como mote para a redistribuição e redimensionamento de ônus e deveres. A isonomia no processo é o que Ada Pellegrini Grinover conceitua como par condicio ou igualdade de armas, definindo-a como "o princípio de equilíbrio de situações, não iguais, mas recíprocas" 40 . Ainda, na perspectiva de Barbosa Moreira, a credibilidade do processo como instrumento de solução de conflitos de interesses depende essencialmente de sua capacidade de oferecer aos respectivos titulares uma perspectiva de equanimidade ${ }^{41}$.

O processo não está imune à realidade em que está inserido, mas, ao contrário, reproduz as vulnerabilidades do plano sociológico. Por esta razão, faz todo o sentido que o Princípio da Paridade de Armas receba especial atenção e seja muito prestigiado em nosso país, que é marcado pela brutal desigualdade econômica, cultural e técnica.

A reversão para resgatar a credibilidade do instrumento é dotá-lo de mecanismos eficazes, proporcionando às partes as mesmas oportunidades e submetendo-as às mesmas limitações e riscos ${ }^{42}$. Este é o real significado do princípio da igualdade do ponto de vista material e que está de acordo com os anseios constitucionais.

Em obra destinada à discussão acerca da igualdade e da vulnerabilidade no processo civil, Fernanda Taturce defende que a distribuição dinâmica do encargo de provar revela-se como um dos mecanismos para resgatar a isonomia material do litigante vulnerável. Argumenta a autora que a vulnerabilidade processual faz destas partes vítimas de suas próprias dificuldades e impossibilidades. Em assim sendo, o descumprimento do encargo probatório não se mostra como opção ao litigante vulnerável, mas é eminentemente premido pelas circunstâncias. Em conclusão, assevera Taturce que a distribuição casuística permite a análise sobre qual das partes têm melhores condições de

\footnotetext{
${ }^{39}$ NERY Jr. Nelson. Princípios do Processo na Constituição Federal: processo civil, penal e administrativo. São Paulo: Revista dos Tribunais, 2009. p. 97.

${ }^{40}$ GRINOVER, Ada Pellegrini. Novas Tendências do Direito Processual. São Paulo: Forense. 1988. p. 7.

${ }^{41}$ MOREIRA, Barbosa. “La Igualdad de las Partes en el Proceso civi”l. Revista de Processo, São Paulo, n. 44. p. 82, out/dez. 1996.

${ }^{42}$ Idem, ibidem. p. 165.
} 
Revista Eletrônica de Direito Processual - REDP.

Rio de Janeiro. Ano 11. Volume 18. Número 1. Janeiro a Abril de 2017

Periódico Quadrimestral da Pós-Graduação Stricto Sensu em Direito Processual da UERJ

Patrono: José Carlos Barbosa Moreira. ISSN 1982-7636. pp. 346-376

www.redp.uerj.br

produzir determinadas provas, podendo-se identificar, assim, quando as vulnerabilidades processuais estão presentes, atuando de forma a equalizar as situações jurídicas no processo $^{43}$.

Outro importante fundamento que serve de substrato constitucional à dinamização dos encargos probatórios refere-se à garantia do acesso à justiça (art. $5^{\circ}, \mathrm{XXXV}, \mathrm{CF} / 88$ ), esta compreendida muito além da mera provocação do Poder Judiciário ou do mero exercício abstrato do direito de ação. O contexto atual é de compreender esta garantia como acesso à ordem jurídica justa ${ }^{44}$, em outros termos, é garantir às partes os corolários decorrentes do devido processo legal e, em consequência, proporcionar técnicas idôneas e adequadas para garantir à parte o direito reclamado e impedir que as regras processuais sejam um obstáculo ao alcance do direito material ${ }^{45}$. A distribuição dinâmica do ônus da prova estimula a melhor instrução probatória, influindo diretamente na qualidade da prestação jurisdicional.

Calmon de Passos, ao refletir sobre o significado do direito compreendido enquanto decisão e julgamento, ressalta a importância do processo como determinante e preeminente para o resultado da norma produzida no caso concreto, obtemperando que "antes de o produto condicionar o processo, é o processo que condiciona o produto" 46 . O autor revela a importância que o processo exerce frente à concretização do direito material, dando ênfase sobre como o instrumento pode alterar a substância a depender da forma como é conduzido e disciplinado ${ }^{47}$. Concluiu Calmon de Passos, ao final, que o processo deixou de ser compreendido como um mero instrumento impotente para interferir na substância, pois ele

\footnotetext{
43 TATURCE, Fernanda. Igualdade e Vulnerabilidade no Processo Civil. Rio de Janeiro: Forense. 2012. P. 317-319.

${ }^{44}$ Watanabe, Kazuo. Assistência judiciária e juizado especial de pequenas causas. Juizado especial de pequenas causas. In: WATANABE, Kazuo (org.). São Paulo: RT, 1985.

45 “A distribuição dinâmica do ônus probatórios, como visto, também decorre de uma interpretação sistêmica do caput e dos incis. XIV e XXXV do art. $5^{\circ}$ da CF/1988, pelos quais se almeja que a distribuição do encargo de provar sirva para o alcance da igualdade material, do devido processo legal e da pacificação com justiça". (BAZZANEZE, Thaís. "Distribuição Dinâmica do Ônus Probatórios; análise à luz do devido processo legal e do acesso à justiça". In: Revista de Processo. São Paulo: Revista dos Tribunais, v. 37, n. 205, març. 2012. p. 79)

${ }^{46}$ CALMON DE PASSOS, José Joaquim. Instrumentalidade do processo e Devido Processo Legal. Revista Diálogo Jurídico. Ano I, Vol. I, n. 1, abril de 2001, Salvador. Disponível em: http://www.direitopublico.com.br/pdf_seguro/REVISTA-DIALOGO-JURIDICO-01-2001-J-J-CALMONPASSOS.pdf. Acesso em 20 de janeiro de 2017. p. 3.

${ }^{47}$ Idem, ibidem. p. 4.
} 
Revista Eletrônica de Direito Processual - REDP.

Rio de Janeiro. Ano 11. Volume 18. Número 1. Janeiro a Abril de 2017

Periódico Quadrimestral da Pós-Graduação Stricto Sensu em Direito Processual da UERJ

Patrono: José Carlos Barbosa Moreira. ISSN 1982-7636. pp. 346-376

www.redp.uerj.br

próprio deve estar condicionado a uma racionalidade imprescindível para cumprir a sua função ${ }^{48}$.

Portanto, a aproximação das normas processuais do direito material e a flexibilização de suas regras para se ajustar às peculiaridades fáticas que perfazem o litígio, justamente como propõe a dinamização do ônus probatório, nada mais é do que a expressão do processo civil atento às exigências da sociedade moderna.

Outro fundamento suscitado pela doutrina para amparar a dinamização das cargas probatórias, que inclusive conta com bastante eco na doutrina argentina, local de origem da teoria dinâmica do ônus da prova ${ }^{49}$, versa sobre o dever processual das partes de conduzirse com lealdade, probidade e boa-fé, dever este que se desdobra no dever de colaboração. Assim, toda a vez que o litigante assume a condição de parte no processo, não é apenas para fazer uso de seus direitos, mas também lhe são determinados deveres, inclusive, deveres de colaboração na produção da prova, para que se possa alcançar a verdade jurídica objetiva ${ }^{50}$. Neste sentido, o NCPC rompe com a tradição adversarial do direito brasileiro e introduz os preceitos de uma litigância cooperativa (art. 60). E sob esta perspectiva, se uma das partes está em melhores condições de trazer os elementos de convicção aos autos, assim deverá proceder ${ }^{51}$.

Importante apenas deixar claro que a proposta de dinamização da distribuição da prova não pretende fazer letra rasa do princípio da segurança jurídica, princípio da mesma estatura constitucional (art. $5^{\circ}$, caput, $\mathrm{CF} / 88$ ) das demais garantias e princípios acima

\footnotetext{
${ }^{48}$ Idem, ibidem. p. 6.

49 A despeito da controvérsia sobre a origem da teoria da distribuição dinâmica dos encargos probatórios, a sua introdução e o seu desenvolvimento são imputados ao argentino Jorge Walter Peyrano. Como magistrado, o autor contemplou pela primeira vez a dinamização dos encargos probatórios em sentença de sua autoria, proferida em caso que versava sobre erro médico, no ano 1978. Tratou-se do ponto de partida para a discussão da teoria pela doutrina e jurisprudência daquele país, desbordando, a partir de então, as hipóteses fáticas de seu cabimento para alcançar outros casos em que a teoria também encontra amplo enquadramento.

${ }^{50}$ Neste sentido: "Não por outra razão, em doutrina, com alguns reflexos jurisprudenciais, tem-se trazido a esta seara a denominada Teoria da carga dinâmica da prova, que outra coisa não consiste senão em nítida aplicação do princípio da boa-fé n campo probatório. Ou seja, deve provar quem tem melhores condições para tal. É logicamente insustentável que aquele dotado de melhores condições de demonstrar os fatos deixe de fazê-lo, agarrando-se em formais distribuições dos ônus de demonstração. O processo moderno não mais compactua com táticas ou espertezas procedimentais e busca, cada vez mais, a verdade". (CARPES, Arthur. “A Distribuição Dinâmica do Ônus da Prova no Formalismo-Valorativo". In: Revista de Direito Processual Civil. Curitiba: Gênesis. n. 39, jan-jun./2006, p. 5-14).

${ }^{51}$ PINHO, Humberto Dalla Bernardina de. "Breves Reflexões sobre o ônus da Prova no CPC/2015". In: Distribuição Dinâmica do ônus da Prova - exegese do artigo 373, par. $1^{\circ}$ e $2^{\circ}$ do NCPC. In: DIDIER Jr., Fredie [et. al. ] (coord.). Direito Probatório. Jus PodiVm. 2016. p.348.
} 
Revista Eletrônica de Direito Processual - REDP.

Rio de Janeiro. Ano 11. Volume 18. Número 1. Janeiro a Abril de 2017

Periódico Quadrimestral da Pós-Graduação Stricto Sensu em Direito Processual da UERJ

Patrono: José Carlos Barbosa Moreira. ISSN 1982-7636. pp. 346-376

www.redp.uerj.br

citados. Flexibilizar a distribuição do ônus da prova não quer dizer ausência de previsibilidade às partes acerca dos critérios de repartição do encargo. Tampouco se trata de poder discricionário outorgado ao órgão julgador. Dinamizar representa apenas moldar o substrato normativo às perspectivas da realidade, de modo a garantir os princípios da igualdade material e do acesso à justiça. E justamente por não se tratar de criação legislativa permeada por abuso ou autoritarismo, faz-se imprescindível deixar claros os limites teóricos- normativos para a sua adequada aplicação, os quais estão bem delineados no Código de Processo Civil atual.

\subsection{Distribuição Dinâmica do Ônus da Prova e o Novo Código de Processo Civil}

A Lei 13.105/15 reproduz em seu artigo 373, caput, a regra inscrita no artigo 333 do CPC/73, que versa sobre a distribuição estática do ônus da prova: “cabe ao autor o ônus dos fatos constitutivos de seu direito e, ao réu, o encargo de demonstrar o fato impeditivo, modificativo ou extintivo do direito do autor". Há, portanto, no NCPC uma autêntica regra, que descreve, de forma prévia e abstrata, o comportamento que as partes deveriam adotar para afastar a sucumbência e também o comportamento que deve ser adotado pelo juiz, no caso de insuficiência de prova apta à formação da convicção sobre os fatos postos na controvérsia.

A novidade legislativa está no parágrafo $1^{\circ}$ do referido dispositivo, que assim dispõe:

"Nos casos previstos em lei ou diante de peculiaridades da causa relacionadas à impossibilidade ou à excessiva dificuldade de cumprir o encargo nos termos do caput ou à maior facilidade de obtenção da prova do fato contrário, poderá juiz atribuir o ônus da prova de modo diverso, desde que o faça por decisão fundamentada, caso em que deverá dar à parte a oportunidade de se desincumbir do ônus que lhe foi atribuído". 
Revista Eletrônica de Direito Processual - REDP.

Rio de Janeiro. Ano 11. Volume 18. Número 1. Janeiro a Abril de 2017

Periódico Quadrimestral da Pós-Graduação Stricto Sensu em Direito Processual da UERJ

Patrono: José Carlos Barbosa Moreira. ISSN 1982-7636. pp. 346-376

www.redp.uerj.br

Note-se que a possibilidade de dinamização do ônus da prova está localizada no parágrafo único do artigo que prevê a regra geral. Isso reforça o argumento de que a sua aplicação é subsidiária e excepcional, devendo apenas ser aplicada quando presentes os requisitos expressamente previstos ${ }^{52}$. Ademais, a dinamização pressupõe a existência de um ônus da prova abstrato e anterior, que será modificado ${ }^{53}$. Portanto, a regra geral mantém-se aquela descrita no caput do artigo em análise.

Desta forma, de forma inédita, o novo CPC contemplou expressamente a dinamização do ônus da prova. Não se trata de absoluta novidade, pois a questão já estava sendo debatida na doutrina e na jurisprudência ${ }^{54}$, considerando que o seu fundamento encontra respaldo na Constituição, conforme já se demonstrou. Ademais, as discussões da dinamização do ônus da prova também giravam em torno das discussões dos Anteprojetos de Código Processual Coletivo ${ }^{55}$, que acabaram não tendo força política suficiente para a sua aprovação.

De todo modo, a sua expressa previsão no NCPC, sem dúvida alguma, concedeu maior segurança jurídica ao instituto, mormente diante da regulamentação do procedimento e dos requisitos para a sua aplicação.

Um dos pontos importantes e essenciais para que a teoria em pauta não se desvirtue dos lindes da justiça é compreendê-la pelo traço da excepcionalidade. A propósito, o requisito da excepcionalidade da dinamização do encargo probatório é defendido até mesmo pelo criador desta teoria ${ }^{56}$, que, por sua vez, é acompanhado pela jurisprudência argentina.

\footnotetext{
52 A versão do PL 166/2010 do Senado a distribuição do ônus da prova estava previsto em artigo diverso da regra geral, deixando dúvidas quanto à subsidiariedade.

53 MACÊDO, Lucas Buril de; Peixoto, Ravi. Ônus da Prova e sua Dinamização. Salvador: JusPodiVm., 2016. p. 141.

${ }^{54}$ Assim já decidiu o STJ: "Embora não tenha sido expressamente contemplada no CPC, uma interpretação sistemática da nossa legislação processual, inclusive com bases constitucionais, confere ampla legitimidade à aplicação da teoria da distribuição dinâmica do ônus da prova, segundo a qual o ônus recai sobre quem tiver melhores condições de produzir a prova, conforme as circunstâncias fáticas do caso". (STJ, REsp 1286704, $3^{\mathrm{a}}$ T., j. 22.10.2013, rel. Min. Nancy Andrighi, DJe 28.10.2013)

${ }_{55}^{5}$ Vide o artigo 11, parágrafos $1^{\circ}$ e $2^{\circ}$ do Anteprojeto de Código de Processo Civil Coletivo.

56 “La procedencia de la solución judicial de un litigio gracias a la aplicación de la regral de la carga de la prueba, debe considerarse de interpretación restrictiva cuando em el curso del respectivo se há producido prueba. En este caso, la debida fundamentación de la resolución respectiva debe incluir um estúdio pormenorizado de todas las pruebas producidas y la explicitación de las razones por las que se la considera insuficientes ara demonstrar lo que se debía provar". (PEYRANO, Jorge Walter. La Regla de la Carga de La Prueba Enfocada como norma de clausura del sistema. Civil Procedure Review, v. 1, n. 3, sep./dec., 2010. Disponível em www.civilprocedurereview.com.Acesso em 30 de janeiro de 2017).
} 
Revista Eletrônica de Direito Processual - REDP.

Rio de Janeiro. Ano 11. Volume 18. Número 1. Janeiro a Abril de 2017

Periódico Quadrimestral da Pós-Graduação Stricto Sensu em Direito Processual da UERJ

Patrono: José Carlos Barbosa Moreira. ISSN 1982-7636. pp. 346-376

www.redp.uerj.br

Os fundamentos constitucionais apresentados servem de base firme para a sua aplicação e legitimação no sistema. O texto expresso no NCPC representa a pedra pacificadora quanto à controvérsia acerca de sua aplicabilidade no ordenamento jurídico brasileiro. Isso, no entanto, não retira o status de regra subsidiária e excepcional. Ao contrário, os rígidos requisitos exigidos no NCPC reafirmam esta qualidade. Neste sentido, é preciso deixar claro que o modo de distribuição descrito no caput do artigo 373 do CPC/15, o estático, deve ser compreendido como regra geral.

A excepcionalidade da dinamização do ônus está preconizada sobre o Princípio da Igualdade. Isso porque, na ampla maioria das vezes, quem alega é efetivamente quem tem melhores condições de provar o fato afirmado quando comparado com aquele que simplesmente o nega. Deste modo, na maioria dos casos, a distribuição do ônus probatório de forma diversa poderia culminar na violação do princípio da igualdade ${ }^{57}$ e, em consequência, comprometer a justeza da decisão. Exige-se, deste modo, a análise minuciosa do caso concreto, sob pena de ofensa ao devido processo legal, afinal, neste ponto reside a dinamicidade proposta na teoria contemporânea do processo civil. Repisase, portanto, que a dinamização do ônus deve ser regra subsidiária, ou seja, quando o princípio da aquisição processual da prova e quando os poderes instrutórios do juiz não permitam a formação de convicção suficiente sobre os fatos ${ }^{58}$.

Esta, sem dúvida, é a melhor perspectiva para se compreender a teoria, até mesmo para evitar que, travestido do escopo de se fazer justiça substancial por meio do processo, acabe por se colimar a resultados injustos e a promover a desigualdade entre as partes, com a imputação de encargos probatórios severos e inexequiíveis ao outro litigante.

$\mathrm{Na}$ linha da excepcionalidade, o parágrafo único do artigo 373 do NCPC impõe rígidos requisitos para que a dinamização do ônus probatório seja autorizada. Faz-se necessária a presença da extrema dificuldade ou impossibilidade na produção da prova pela parte a quem incumbiria o ônus, segundo a regra estática e, não obstante, a demonstração de melhores condições da parte contrária na produção da prova. Importante compreender que a excessiva dificuldade de produção de prova deve ser somada à maior facilidade de

${ }^{57}$ CARPES, Arthur Thompsen. Notas sobre a Interpretação do Texto e Aplicação das Normas sobre o Ônus (dinâmico) da Prova no Novo Código de Processo Civil. In: DIDIER Jr., Fredie (coord.). Direito Probatório. Salvador: JusPodiVm. 2016. p. 202.

${ }^{58}$ MACÊDO, Lucas Buril de; PEIXOTO, Ravi. Ônus da Prova e sua Dinamização. Salvador: JusPodiVm, 2016. 89. 
Revista Eletrônica de Direito Processual - REDP.

Rio de Janeiro. Ano 11. Volume 18. Número 1. Janeiro a Abril de 2017

Periódico Quadrimestral da Pós-Graduação Stricto Sensu em Direito Processual da UERJ

Patrono: José Carlos Barbosa Moreira. ISSN 1982-7636. pp. 346-376

www.redp.uerj.br

uma das partes de se desincumbir da produção probatória. Registre-se, portanto, que se trata de requisitos cumulativos ${ }^{59}$.

Como se verifica, o NCPC rejeitou a proposta inserta no Projeto de Lei 3.015/08 ${ }^{60}$, que preconizava a distribuição do encargo condicionada à complexidade do caso concreto. E o fez com acerto, considerando que é a tutela do direito material, expressa pela dificuldade de uma das partes produzir a prova em detrimento de outra que pode desencadear a distribuição diversa daquela descrita no caput do dispositivo em comento ${ }^{61}$.

Os termos "impossibilidade" ou "excessiva dificuldade" de cumprir o encargo podem se concretizar em decorrência das barreiras informacionais opostas à parte a quem caberia o ônus probatório segundo a regra estática. Em contrapartida, a parte contrária deve estar em posição mais privilegiada no que pertine à referida condição informacional. Em suma, deve restar demonstrada a assimetria quanto às informações entre as partes litigantes.

Sobre este aspecto, tem-se entendido que a hipossuficiência econômica, por si só, não ensejaria a modificação do ônus de provar. Melhor explicando, a dificuldade de custear a prova não conduz à sua transferência à parte contrária. As questões relacionadas ao custeio da prova, assim como as demais despesas processuais, devem ser resolvidas nos termos da assistência jurídica gratuita, matéria disciplinada pela Lei 1.060/50 ${ }^{62}$.

A doutrina costuma aproximar o conceito da efetiva dificuldade ou impossibilidade de a parte onerada produzir a prova do fato alegado àquele utilizado para definir o significado de prova diabólica. Cuida-se de expressão utilizada pela doutrina para "fazer referência àqueles casos em que a prova da veracidade da alegação a respeito de um fato é

\footnotetext{
${ }^{59}$ Sobre a cumulatividade dos requisitos: "É evidente que nem toda disparidade de condições probatórias justificará a dinamização, que deve ser utilizada tão somente nas hipóteses em que haja grande dificuldade para a produção de prova de um lado e facilidade do outro. A mera facilidade para a produção de prova de uma das partes, desacompanhada da dificuldade de produção da parte adversária não é uma situação apta a justificar a modificação dos encargos probatórios. Além disso, uma simples dificuldade na produção de uma prova não permite a utilização da técnica da dinamização, mas tão somente quando a produção probatória for extremamente difícil ou praticamente impossível. (Idem, ibidem. p. 174).

${ }^{60}$ Projeto de Lei da Câmara dos Deputados que tinha o escopo de alterar o artigo 333 do CPC/73.

${ }^{61}$ CAMBI, Eduardo. Teorias das Cargas Probatórias Dinâmicas (Distribuição Dinâmica do ônus da Prova) exegese do artigo 373, par. $1^{\circ}$ e $2^{\circ}$ do NCPC. In: DIDIER Jr., Fredie [et. al. ] (coord.). Direito Probatório. Jus PodiVm. 2016. p. 255.

62 “A inversão do ônus da prova (art. $6^{\circ}$, VIII, do CDC e art. $3^{\circ}, \mathrm{V}$, da Lei n. 1.060/1950) não tem o efeito de obrigar a parte contrária a pagar as custas da prova requerida pelo consumidor, porém ela sofre as consequiências de não produzi-la”. (REsp 435.155-MG, Rel. Min. Carlos Alberto Menezes Direito, julgado em 11/2/2003).
} 
Revista Eletrônica de Direito Processual - REDP.

Rio de Janeiro. Ano 11. Volume 18. Número 1. Janeiro a Abril de 2017

Periódico Quadrimestral da Pós-Graduação Stricto Sensu em Direito Processual da UERJ

Patrono: José Carlos Barbosa Moreira. ISSN 1982-7636. pp. 346-376

www.redp.uerj.br

extremamente difícil, nenhum meio de prova é capaz de permitir tal demonstração"63.

Trata-se de limite material à aplicação da distribuição dinâmica, ou seja, evitar a formação da prova diabólica. E, em assim sendo, de forma alguma visa a compensar a inércia ou a inatividade processual do litigante inicialmente onerado ${ }^{64}$.

Cumulativamente com este primeiro requisito, deve-se observar se esta extrema onerosidade ou impossibilidade também não se coloca para a outra parte. Em outros termos: não é possível criar prova impossível ou diabólica para a parte contrária, fenômeno denominado de prova diabólica reversa. Por esta razão, exige-se também como requisito para a incidência desta teoria a efetiva facilidade de contraprova pela parte adversa. Assim, a parte ex adversa deve ter melhores condições de produzir provas capazes de demonstrar a inocorrência da violação do direito, caso contrário, não se está reequilibrando as armas processuais das partes litigantes, mas promovendo um verdadeiro desequilíbrio. Tem-se, portanto, que a isonomia é, a um só tempo, fundamento e limite de aplicação da teoria ${ }^{65}$.

Outro ponto que merece ser abordado é a necessidade de que a dinamização do ônus probatório recaia sobre um ponto específico, declarado pelo magistrado e não sobre a totalidade dos fatos controvertidos, de uma maneira genérica. Assim, faz-se imprescindível que, para cada fato, o magistrado fundamente a presença dos requisitos de extrema dificuldade ou impossibilidade para uma parte e a facilidade para a parte contrária ${ }^{66}$. Desta maneira, padece de error in procedendo, por vício na fundamentação, a decisão que se limita a genericamente inverter os ônus probatórios ${ }^{67}$.

\footnotetext{
${ }^{63}$ CÂMARA, Alexandre Freitas. "Doenças Preexistentes e Ônus da Prova: o problema da prova diabólica e uma possível solução". In: Revista Dialética de Direito Processual. São Paulo: Dialética, 2005, n. 31. p. 12.

${ }^{64}$ CAMBI, Eduardo. Teorias das Cargas Probatórias Dinâmicas (Distribuição Dinâmica do ônus da Prova) exegese do artigo 373, par. $1^{\circ}$ e $2^{\circ}$ do NCPC. In: DIDIER Jr., Fredie [et. al. ] (coord.). Direito Probatório. Jus PodiVm. 2016. p. 262.

${ }^{65}$ LUCON, Paulo Henrique; COSTA, Guilherme Recena. Formalismo Processual e Dinamização do Ônus da Prova. In: Processo Civil: estudos em homenagem ao professor doutor Carlos Alberto Álvaro de Oliveira. São Paulo: Atlas, 2012.

${ }^{66}$ Esta questão já foi objeto de discussão em torno do artigo $6^{\circ}$, inciso VIII do CDC: “À luz das conclusões já alcançadas, decorre naturalmente que, para cada fato probando, deve haver a análise da presença ou não da hipossuficiência. Ou seja, uma vez presente esse requisito quanto a um particular fato controvertido, isso não significa que todo o ônus probatório será invertido em favor do consumidor. A inversão se restringe àquele ponto para o qual haja uma disparidade quanto ao controle da informação entre consumidor e fornecedor". (SICA, Heitor Vitor Mendonça. "Questões Velhas e Novas sobre a Inversão do Ônus da Prova (art. 6º VIII, do CDC)”. Revista de Processo, São Paulo: RT, n. 146, p. 53, abril-jul. 2007).

${ }^{67}$ MACÊDO, Lucas Burilde; PEIXOTO, Ravi. Ônus da Prova e sua Dinamização. Salvador: JusPodiVm. 2016. p. 172.
} 
Revista Eletrônica de Direito Processual - REDP.

Rio de Janeiro. Ano 11. Volume 18. Número 1. Janeiro a Abril de 2017

Periódico Quadrimestral da Pós-Graduação Stricto Sensu em Direito Processual da UERJ

Patrono: José Carlos Barbosa Moreira. ISSN 1982-7636. pp. 346-376

www.redp.uerj.br

Por fim, também como requisito para a distribuição dinâmica, tem-se a

imprescindibilidade de franquear o contraditório prévio entre as partes. Tal questão tem implicações diretas no momento adequado para a distribuição dinâmica. Como bem ponderado por Eduardo Cambi, a distribuição dinâmica não deve ser arbitrária, tampouco servir para prejulgar a causa. Para tanto, faz-se imprescindível o respeito das garantias constitucionais das partes, como a ampla defesa e o contraditório, afastando, assim, decisões surpresas ${ }^{68}$.

Nesta linha, com vistas a pacificar o entendimento acerca do momento adequado para que o magistrado promova a distribuição dinâmica, questão que já foi objeto de controvérsia perante o $\mathrm{STJ}^{69}$, o artigo 373 , parágrafo $1^{\circ}$ do $\mathrm{CPC}$ deixou claro que deve a decisão ocorrer antes do início da fase instrutória, a fim de que a parte responsável pelo encargo possa ter oportunidade de cumpri-la. Neste caso, preserva-se a ampla defesa, o contraditório, inclusive com o direito de a parte onerada insurgir-se contra a decisão, já que se trata de hipótese legal expressa de interposição de agravo de instrumento, nos termos do artigo 1.015, inciso XI, da Lei 13.105/15.

Em assim fazendo, o NCPC contemplou não apenas o aspecto objetivo do ônus da prova, mas também o subjetivo. Deste modo, o ônus da prova mantém-se como regra de julgamento (aspecto objetivo), e, ainda, serve de estímulo à parte para que produza as provas visando a influenciar convencimento do juiz (aspecto subjetivo). Andou bem o Código em não desprezar o aspecto subjetivo, considerando que este não atende apenas ao interesse privado da parte, mas também observa o interesse público, pois, ao final, possibilita-se a entrega da melhor prestação jurisdicional, interesse do Estado ${ }^{70}$. Como já afirmado, incentivam-se os litigantes a despender esforços para impedir a sucumbência, descortinando uma atuação de cooperação entre si. Da mesma maneira, ilide as decisões surpresas, que desprezam o contraditório prévio das partes, e observa os vetores do

\footnotetext{
${ }^{68}$ CAMBI, Eduardo. Op.cit., 342-343.

${ }^{69}$ A controvérsia foi fomentada pela discussão do momento adequado para a inversão do ônus da prova, inscrita no artigo $6^{\circ}$, VIII do CDC. A Terceira Turma do STJ afirmava ser regra de julgamento, enquanto a Quarta Turma entendia ser regra de atividade. A questão demandou manifestação da Segunda Seção e, ao final, sedimentou o entendimento de que a distribuição do ônus probatório é regra de julgamento e também norma de instrução, o que exigiria a ciência prévia das partes antes do proferimento da sentença. (Resp 802.832/MG, rel. Paulo de Tarso Sanseverino, j. 13.04.2011).

70 SILVEIRA, Bruna Braga da. A Distribuição Dinâmica do Ônus da Prova no CPC-15. In: Direito Probatório. Salvador: JusPodiVm. 2016. p. 218.
} 
Revista Eletrônica de Direito Processual - REDP.

Rio de Janeiro. Ano 11. Volume 18. Número 1. Janeiro a Abril de 2017

Periódico Quadrimestral da Pós-Graduação Stricto Sensu em Direito Processual da UERJ

Patrono: José Carlos Barbosa Moreira. ISSN 1982-7636. pp. 346-376

www.redp.uerj.br

princípio da cooperação, em que o dever de consulta revela-se um de seus elementos, consoante se infere do artigo $9^{\circ 71}$ e $10^{\circ 72}$ do NCPC.

Vale apenas ressaltar que o momento adequado para a distribuição do ônus da prova não, necessariamente, será no saneamento do processo. O art. 373, parágrafo único do CPC apenas exige prévia oportunidade às partes para se desincumbirem do ônus que lhe foi atribuído. Não obstante ser o saneamento momento bastante oportuno para que isso aconteça, nada impede que o magistrado faça posteriormente, desde que respeite o contraditório e possibilite às partes oportunidade para se desincumbir deste ônus imputado.

De todo modo, tais razões devem ser demonstradas pelo órgão julgador, por meio de uma decisão devidamente fundamentada, demonstrando racionalmente, à luz do caso concreto, a presença de todos os requisitos legais exigidos. Por se tratar de um ato interpretativo e não volitivo, a distribuição dinâmica deve estar respaldada por razões jurídicas sólidas, coerentes, claras. A despeito de se tratar de um dever constitucional (art. 93, IX, CF/88), o próprio artigo que regulamenta a distribuição dinâmica do ônus da prova (art. 373, par. Único, CPC) reafirma a necessidade da devida fundamentação, de modo a ressaltar a importância da exposição das razões técnicas, fáticas e valorativas do órgão julgador, que irão preencher os conceitos jurídicos indeterminados. Como se trata de um dispositivo que amplia os poderes do órgão julgador e que contém conceitos jurídicos indeterminados, a sua aplicação deve, necessariamente, ser acompanhada de um maior rigor no dever de fundamentação. E, por fim, concorre ainda mais para o dever de fundamentação do magistrado quando da aplicação da dinamização do ônus probatório a concretização do princípio da fundamentação analítica inserta no NCPC, prevista genericamente no artigo 11 e explicitado no artigo 489, parágrafo $1^{\circ}$ do NCPC.

Com efeito, a teoria da dinamização do ônus da prova, assim como tem seus fundamentos pautados no devido processo legal constitucional, também deve observar requisitos e parâmetros legais para a sua integral compatibilidade com o próprio sistema

\footnotetext{
71 “Art. 9o Não se proferirá decisão contra uma das partes sem que ela seja previamente ouvida. Parágrafo único. O disposto no caput não se aplica: I - à tutela provisória de urgência; II - às hipóteses de tutela da evidência previstas no art. 311, incisos II e III; III - à decisão prevista no art. 701”.

72 “O juiz não pode decidir, em grau algum de jurisdição, com base em fundamento a respeito do qual não se tenha dado às partes oportunidade de se manifestar, ainda que se trate de matéria sobre a qual deva decidir de ofício".
} 
Revista Eletrônica de Direito Processual - REDP.

Rio de Janeiro. Ano 11. Volume 18. Número 1. Janeiro a Abril de 2017

Periódico Quadrimestral da Pós-Graduação Stricto Sensu em Direito Processual da UERJ

Patrono: José Carlos Barbosa Moreira. ISSN 1982-7636. pp. 346-376

www.redp.uerj.br

processual, de modo que cumpra o seu real papel de concorrer para a melhor equalização das relações processuais e jamais criar novas desigualdades.

\section{CONCLUSÃO}

No presente trabalho, foram traçadas as premissas conceituais acerca das perspectivas do ônus probatório, seguindo-se da análise de seus efeitos jurídicos para a atividade das partes e para o julgamento da demanda.

Passou-se, então, a discutir sobre as teorias que determinam o encargo probatório às partes. Iniciou-se com a análise do amparo doutrinário da teoria estática do ônus da prova, demonstrando a sua racionalidade e, inclusive, a sua adequação para reger grande parte dos casos.

De outro vértice, demonstrou-se que a teoria estática é, em determinados casos, insuficiente para respaldar importantes garantias constitucionais, como a isonomia processual e, em última análise, o próprio acesso à justiça.

Surge então a teoria dinâmica, que teve a sua gênese no direito argentino e neste país teve largo desenvolvimento em razão de discussões que tiveram como palco a doutrina e a jurisprudência.

No Brasil, a teoria também encontrou adeptos na doutrina e, respaldado na normativa constitucional, a jurisprudência também acolheu a possibilidade de dinamização da prova em determinadas matérias.

Por fim, a distribuição dinâmica foi contemplada expressamente no novo CPC, quando então foram elencados pressupostos materiais e processuais para evitar que a referida dinamização representasse arbitrariedade e abuso judicial.

\section{REFERÊNCIAS BIBLIOGRÁFICAS}

ARANZI, Roland. La Prueba en el Proceso Civil. Buenos Aires: Ediciones La Rocca. AZEVEDO, Luiz Carlos de. CRUZ E TUCCI, José Rogério. Lições de História do Processo Civil Romano. São Paulo: Revista dos Tribunais, 2001. 
Revista Eletrônica de Direito Processual - REDP.

Rio de Janeiro. Ano 11. Volume 18. Número 1. Janeiro a Abril de 2017

Periódico Quadrimestral da Pós-Graduação Stricto Sensu em Direito Processual da UERJ

Patrono: José Carlos Barbosa Moreira. ISSN 1982-7636. pp. 346-376

www.redp.uerj.br

BARBOSA MOREIRA, Barbosa. A Função Social do Processo Civil Moderno e o Papel

do Juiz e das Partes na Direção e na Instrução do Processo. In: Revista de Processo.

São Paulo, n. 37, jan/mar. 1985. p. 140-150.

. Julgamento e Ônus da Prova. In: Temas de Direito Processual: segunda série.

Saraiva, São Paulo, 1988.

. La Igualdad de las partes en el proceso civil. Revista de Processo. São Paulo:

Revista dos Tribunais, n. 44. p. 82, out/dez. 1996.

BAUR, Fritz. O Papel Ativo do Juiz. In: Revista de Processo. São Paulo: Revista dos Tribunais, n. 27, jul./set., 1982. p. 186-189.

BAZZANEZE, Thaís. Distribuição Dinâmica do Ônus Probatórios; análise à luz do devido processo legal e do acesso à justiça. In: Revista de Processo. São Paulo: Revista dos Tribunais, v. 37, n. 205, març. 2012. p. 55-87.

BEDAQUE, José Roberto dos Santos. Direito e Processo: influência do Direito Material sobre o processo. São Paulo: Malheiros, 2009. p. 15

Poderes Instrutórios do Juiz. São Paulo: Revista dos Tribunais. 2009.

BERIZONCE, Roberto O. El princípio de colaboración procesal y el régimen de la prueba em el proceso por audiências. In: Processo Civil em transformación. Platense, La Plata, 2008.

CALMON DE PASSOS, José Joaquim. Instrumentalidade do processo e Devido Processo Legal. Revista Diálogo Jurídico. Ano I, Vol. I, n. 1, abril de 2001, Salvador. Disponível em: http://www.direitopublico.com.br/pdf_seguro/REVISTADIALOGO-JURIDICO-01-2001-J-J-CALMON-PASSOS.pdf. Acesso em 20 de janeiro de 2017.

CAMBI, Eduardo. A Prova Civil: admissibilidade e relevância. São Paulo: Revista dos Tribunais. 2006.

- Teorias das Cargas Probatórias Dinâmicas (Distribuição Dinâmica do ônus da Prova) - exegese do artigo 373, par. $1^{\circ}$ e $2^{\circ}$ do NCPC. In: DIDIER Jr., Fredie [et. al. ] (coord.). Direito Probatório. Jus PodiVm. 2016.

CAMPANELli, Luciana Amicucci. Poderes Instrutórios do Juiz e a Isonomia Processual. São Paulo: Juarez de Oliveira. 2006. 
Revista Eletrônica de Direito Processual - REDP.

Rio de Janeiro. Ano 11. Volume 18. Número 1. Janeiro a Abril de 2017

Periódico Quadrimestral da Pós-Graduação Stricto Sensu em Direito Processual da UERJ

Patrono: José Carlos Barbosa Moreira. ISSN 1982-7636. pp. 346-376

www.redp.uerj.br

CARNELUTTI, Francesco. Sistema de Derecho Procesal Civil. Tradução Niceto Alcalá-

Zamora y Cartillo y Santiago Sentís Melendo. Buenos Aires: UTHEA. 1944.

CARPES, Arthur. A Distribuição Dinâmica do Ônus da Prova no Formalismo-Valorativo.

In: Revista de Direito Processual Civil. Curitiba: Gênesis. n. 39, jan-jun./2006, p. 5-14.

- Notas sobre a interpretação do texto e aplicação das normas sobre o ônus (dinâmico) da prova no Novo Código de Processo Civil. In: DIDIER Jr., Fredie (coord.). Direito Probatório. Salvador: JusPodiVm. 2016.

Ônus Dinâmico da Prova. Livraria do Advogado: Porto Alegre, 2010.

CHIOVENDA, Giuseppe. Instituições do Direito Processual Civil. v. 2., Trad. Paolo

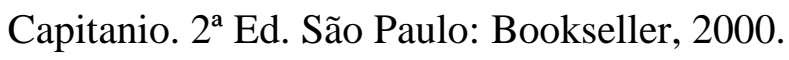

CINTRA, Antonio Carlos de Araújo; GRINOVER, Ada Pellegrini; DINAMARCO,

Cândido Rangel. Teoria Geral do Processo. São Paulo: Malheiros: São Paulo. 2008.

COUTO, Camilo José D’Avila. Dinamização do ônus da Prova: teoria e prática. Tese de

Doutorado. Universidade de São Paulo. 2011.

CREMASCO, Suzana Santi. A Distribuição Dinâmica do Ônus da Prova. Rio de Janeiro: GZ Editora, 2009.

CRUZ E TUCCI, José Rogério. Lições de História do Processo Civil Romano. São

Paulo: Revista dos Tribunais, 2001.

DALLARI, Dalmo de Abreu. O Poder dos Juízes. São Paulo: Saraiva. 1966.

DALL'AGNOL Jr., Antonio. Distribuição Dinâmica do Ônus Probatório. In: Revista

Jurídica. Porto Alegre: Notadez/Fonte do Direito, n. 280, fevereiro de 2001.

DINAMARCO, Cândido Rangel. DINAMARCO, Cândido Rangel. A Instrumentalidade do Processo. São Paulo: Malheiros, 2009.

. Instituições de Direito Processual Civil. Vol. I. São Paulo: Malheiros, 2009.

FORNACIARI, Fernando Hellmeister Clito. Ônus da Prova no Processo Civil.

Dissertação de Mestrado na Faculdade de Direito da Universidade São Paulo, sob orientação do Professor José Rogério Cruz e Tucci. São Paulo, 2005.

GARCÍA GRANDE, Maximiliano. Cargas Probatórias Dinámicas: ni nuevas, ni argentinas, ni aplicables. Disponível em http://www.e- 
Revista Eletrônica de Direito Processual - REDP.

Rio de Janeiro. Ano 11. Volume 18. Número 1. Janeiro a Abril de 2017

Periódico Quadrimestral da Pós-Graduação Stricto Sensu em Direito Processual da UERJ

Patrono: José Carlos Barbosa Moreira. ISSN 1982-7636. pp. 346-376

www.redp.uerj.br

derecho.org.ar/congresoprocesal/cargas\%20Probatorias\%20Din\%E1micas\%20_Gran de_pdf.. .).

GIANINI, Leadro J. Principio de colaboración y carga dinâmica de la prueba (uma distinción necesaria). Disponível em: http://papers.ssrn.com/sol3/papers.cfm?abstract_id=2458246. Acesso em 29 de novembro de 2015.

GRINOVER, Ada Pellegrini. As Garantias Constitucionais do Direito de Ação. São Paulo: Revista dos Tribunais, 1973.

HIGINO NETO, Vicente. Ônus da Prova: teorias da redução do módulo da prova e das provas dinâmicas e compartilhadas. Curitiba: Juruá. 2010.

LEONEL, Ricardo de Barros. Manual do Processo Coletivo. São Paulo: Revista dos Tribunais, 2011.

LOPES, João Batista. Direito à Prova, Discricionariedade e Fundamentação da Sentença. In: In: DIDIER Jr., Fredie [et. al. ] (coord.). Direito Probatório. Jus PodiVm. 2016.

LUCON, Paulo Henrique; COSTA, Guilherme Recena. Formalismo Processual e Dinamização do Ônus da Prova. In: Processo Civil: estudos em homenagem ao professor doutor Carlos Alberto Alvaro de Oliveira. São Paulo: Atlas, 2012.

MACÊDO, Lucas Buril de; Peixoto, Ravi. Ônus da Prova e sua Dinamização. Salvador: JusPodiVm., 2016.

MARINONI, Luiza Guilherme. Técnica Processual e Tutela dos Direitos. São Paulo: Revista dos Tribunais. 2010.

MARINONI, Luiz Guilherme; MITIDIEIRO, Daniel. O Projeto do CPC. São Paulo: Revista dos Tribunais.

MARINONI, Luiz Guilherme. ARENHART, Sérgio Cruz.. Prova. São Paulo: Editora dos Tribunais. 2009.

MATOS, Cecília. O Ônus da Prova no Código de Defesa do Consumidor. Dissertação de Mestrado apresentada à Faculdade de Direito da Universidade São Paulo, sob orientação do professor Kazuo Watanabe. São Paulo, 1993.

MICHELI, Gian Antonio. La carga de la prueba. Buenos Aires: Ed. Ejea, 1961.

MORELLO, Augusto M. El proceso justo: del Garantismo Formal a la Tutela Efectiva de los Derechos. La Plata. La Plata Platense-Abelede Perrot. 1994. 
Revista Eletrônica de Direito Processual - REDP.

Rio de Janeiro. Ano 11. Volume 18. Número 1. Janeiro a Abril de 2017

Periódico Quadrimestral da Pós-Graduação Stricto Sensu em Direito Processual da UERJ

Patrono: José Carlos Barbosa Moreira. ISSN 1982-7636. pp. 346-376

www.redp.uerj.br

NERY Jr. Nelson. Princípios do Processo na Constituição Federal: processo civil, penal e administrativo. São Paulo: Revista dos Tribunais, 2009.

PEYRANO, Jorge Walter. El Derecho Procesal Postmoderno. In: Revista de Processo.

Ano 21, n. 81, São Paulo, Revista dos Tribunais, jan./març. 1996. p. 141-144.

. Informe sobre la Doctrina de las Cargas Probatórias Dinámicas. In: O Processo

em Perspectiva: jornadas brasileiras de direito processual. Homenagem a José

Carlos Barbosa Moreira. MENDES, Aluisio Gonçalves de Castro; WAMBIER,

Teresa Arruda Alvim. São Paulo: Revista dos Tribunais. 2013.

. La Regla de la Carga de La Prueba enfocada como norma de clausura del sistema.

Civil Procedure Review, v. 1, n. 3, sep./dec., 2010. Disponível em Www.civilprocedurereview.com.Acesso em 28 de novembro de 2015.

PINHO, Humberto Dalla Bernardina de. Breves Reflexões sobre o ônus da Prova no CPC/2015. In: DIDIER Jr., Fredie [et. al.] (coord.). Direito Probatório. Jus PodiVm. 2016.

PIRES, Cristiane Pedroso Pires. Distribuição Dinâmica do ônus da Prova. Mestrado em Direito pela Universidade São Paulo sob orientação do Professor José Carlos Baptista Puoli. São Paulo, 2014.

PISANI, Andrea Proto. Público e Privado no Processo Civil. Revista da Emerj, v. 4, n. $16,2001$.

PUOLI, José Carlos Baptista. Os Poderes do Juiz e as Reformas do Processo Civil. São Paulo: Editora Juarez, 2002.

ROSENBERG, Leo. Tratado de derecho procesal civil. v. 2. 1ª. ed., Buenos Aires: EJEA, 1955.

SANTOS, Moacyr Amaral. Comentários ao Código de Processo Civil. Rio de Janeiro: Forense, 1981.

SANTOS, Sandra Aparecida Sá dos. A Inversão do Ônus da Prova. São Paulo: Revista dos Tribunais.

SICA, Heitor Vitor Mendonça. Questões velhas e novas sobre a inversão do ônus da prova (art. 6º VIII, do CDC). Revista de Processo, São Paulo: RT, n. 146, p. 53, abril-jul. 2007. 
Revista Eletrônica de Direito Processual - REDP.

Rio de Janeiro. Ano 11. Volume 18. Número 1. Janeiro a Abril de 2017

Periódico Quadrimestral da Pós-Graduação Stricto Sensu em Direito Processual da UERJ

Patrono: José Carlos Barbosa Moreira. ISSN 1982-7636. pp. 346-376

www.redp.uerj.br

SILVEIRA, Bruna Braga da. A distribuição dinâmica do ônus da prova no CPC-15. In:

Direito Probatório. Salvador: JusPodiVm. 2016.

TATURCE, Fernanda. Igualdade e Vulnerabilidade no Processo Civil. Rio de Janeiro: Forense, 2012.

WATANABE, Kazuo. Assistência judiciária e juizado especial de pequenas causas.

Juizado especial de pequenas causas. WATAnabe, Kazuo (org.). São Paulo: RT, 1985.

. Código Brasileiro de Defesa do Consumidor: comentado pelos autores do anteprojeto. Vol. II. GRINOVER, Ada Pellegrini; WATANABE, Kazuo; NERY Jr. Nelson (org). Rio de Janeiro: Forense, 2011.

YOSHIKAWA, Eduardo Henrique de Oliveira. Considerações sobre a teoria da distribuição do ônus da prova. In: Revista de Processo. vol. 115. Março. 2012. 